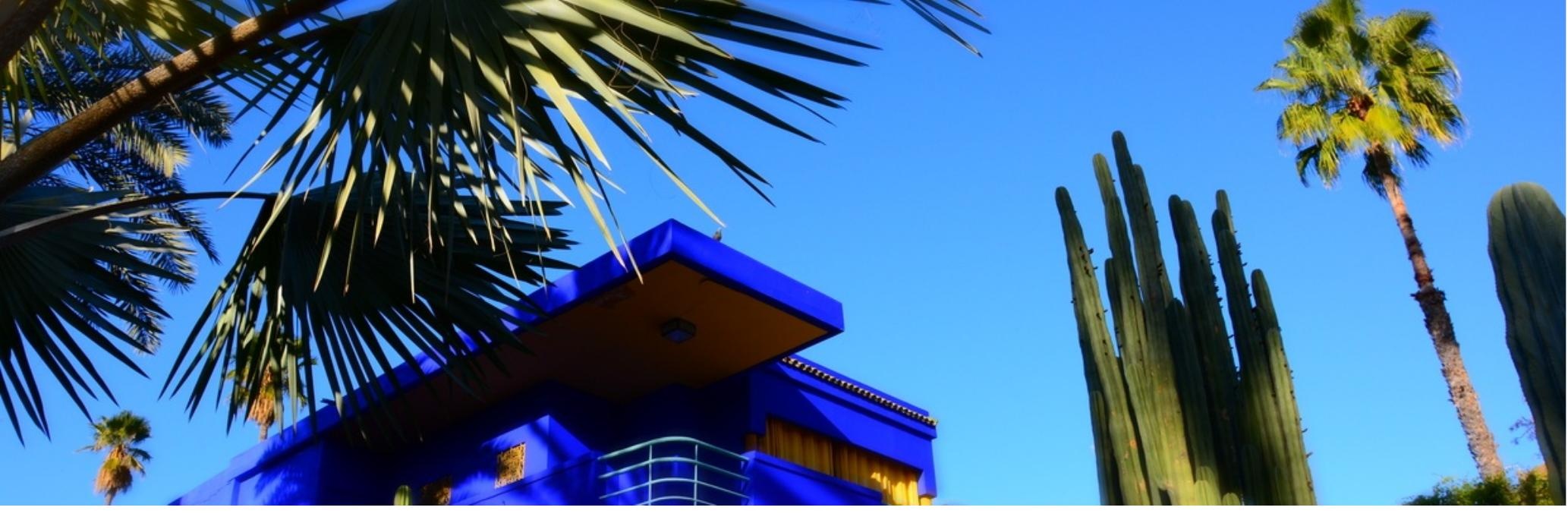

Building Rating System: Kosovar imperative in sustainable context

Authors: $\quad$ Bujar Q. Bajçinovci, Violeta Nushi

Submitted:

18. February 2018

Published:

19. February 2018

Volume:

Issue:

Affiliation:

Languages:

Keywords:

5

2

University of Prishtina, Faculty of Civil Engineering and Architecture, Kosovo

English

Sustainable building; Building rating system; Sustainability indicators.

DOI: $\quad$ 10.17160/josha.5.2.387

Journal of Science,

Humanities and Arts 


\title{
Building Rating System: Kosovar imperative in sustainable context
}

\author{
Violeta Nushi ${ }^{1}$, Bujar Bajçinovci ${ }^{* 1}$ \\ ${ }^{1}$ University of Prishtina, Faculty of Civil Engineering and Architecture, Kosovo. \\ Email: violeta.nushi@uni-pr.edu; Corresponding author “bujar.bajcinovci@uni-pr.edu
}

\begin{abstract}
The purpose of this paper is to identify and establish an understanding for the importance of Building Rating System (BRS) and insights of a detailed survey of the building's specifications in compliance literally stated in requirements of Construction Industry Law in Kosovo. BRS will be used as a comprehensive tool to deliver a report to the respective governmental institution and property developer. As an important part of the sustainable construction delivery system, sustainable BRS plays an essential role in implementing the sustainable principles into the construction industry and assessing the building's rating. The research adopts comprehensive literature reviews from numerous published sources, as journals, government reports, published thesis and website document focusing study on BRS contributions. Sustainable development indicators in securing the interest of Construction Industry in Kosovo will be partially spot lighted by research questions: "What is BRS role into sustainable development, environment, architecture and construction in context of Kosovo? How could BRS response over the law systems among decision makers in Kosovo?" Establishing the BRS system is an essential and/or added value to the government now, as BRS adoption accelerates, must meet the institutional mandate, and thus make closer links between the construction industry and decisionmaking government institutions. Expected outcomes on different levels, outlined in this paper, will address BRS as a minimum tool in near future, starting from educational institutions, designers, builders or clients, for developing a sustainable construction with sustainable architectural and construction concepts and competencies.
\end{abstract}

Keywords: Sustainable building; Building rating system; Sustainability indicators.

\section{INTRODUCTION}

\section{The significance for developing a model for BRS}

The world population has been increasing in a startling way in the last decades. To better understand the rapid population growth, world population reached one billion people by the year 1804, increased to 2 billion in 1927, three billion in 1960, 4 billion in 1974, 5 billion in 1987 and finally reached 6 billion in 1999. The world population in 2010 has reached 6.850 billion people and is expected to reach the 8 billion in 2018 [1]. This major increase in world population combined with the lifestyle of today's society, which is beginning to be adopted by developing countries, is causing a great demand for the natural resources of the planet. This fact is being a major cause of the global crisis that the world 
is experiencing nowadays. If the entire world's population will be living in a European's lifestyle, it would take two and a half planets to supply resources for the entire population. Global warming, a major cause of environmental problems, result mainly from the increased greenhouse gases emissions to the atmosphere. Some of the main gases are carbon dioxide, methane, nitrous oxide and fluorocarbons, which are derived mainly, form burning fossil fuels. This phenomenon has caused several consequences for the world's environment as, among others, increase of average sea level, climate changes, biodiversity loss, and desertification, e.g. 12 of the 13 warmest years ever have occurred since 1995; in year 2005 the average global temperature was $0.76{ }^{\circ} \mathrm{C}$ above the average temperature of the pre-industrial era and it is expected that by the end of this century the temperature will increase 1.8 to $4.0{ }^{\circ} \mathrm{C}$ [2].

The energy consumption is one of the most important factors in the quest for sustainable development and leads to global warming. Energy consumption is the main responsible for emissions of greenhouse gases in the EU. It is also estimated that the construction sector accounts for about $35 \%$ of greenhouse gas emissions. Thus, the efficient use of energy is certainly one of the most important ways to minimize the environmental problems; however, the demand for energy is increasing worldwide. The International Energy Agency predict that the global energy demand will increase by more than $50 \%$ by 2030 if politics remain unchanged and more than $60 \%$ of this increase respect to developing countries [3].

Beside above-mentioned fields, according to European Environment Agency, in 2005 Europe produced 1300 million tons of waste, equivalents to 3.5 tons of waste per capita and $518 \mathrm{~kg}$ of Municipal Solid Waste. Moreover, protecting biodiversity is also seen as an important factor against the greenhouse effect, since the photosynthesis of plants provide an important natural mechanism for storing huge amounts of carbon. Water is also one of the essential elements for life on the planet. It is an invaluable resource for the continuity of human life, not only for drinking, but it is also essential for the production of other food resources. In fact, it takes a lot more water to produce food than the direct consumption. The needs of drinking water per person per day are 2 to 4 liters, but it is needed 2000 to 5000 liters of water daily to produce the food for one person. [4]

Increased attention to sustainable development is collaterally increasing the focus to sustainable environment, consequently the construction sector to build more sustainable buildings. In this regard have been proposed several sustainable development indicators and/or building rating systems. The worldwide dissemination of sustainable building 
rating systems could be considered as an exponential variable for the evaluation of sustainable development indicators in different geographical contexts. Available building rating systems span from energy consumption evaluation systems to life cycle analysis and total quality assessment systems. In these last systems, a multi-dimensional approach is proposed, as several building ratings are evaluated separately before being considered together. A research for sustainability assessment in the construction sector in relation to rating systems and rated buildings are provided data to discuss construction characteristics that, currently, aim at being defined as sustainable. In this case it was concluded by researchers [5], that building energy performance is considered the most important criterion in sustainability rating systems, and the least achieved one in sustainability assessments. In contrast, other performance ratings of the building, such as water efficiency or indoor air quality, are achieved with a high rate of success in sustainability assessments.

Furthermore, the research related with regional cites and their growth rapidly over the past decade as a result of global urbanization shows that the build environment displays a major challenge. A performance of Sustainable Building Management is the key to solve a serious problem when responsible authorities are encouraged managing efficiently social, spatial and environmental consequences due to fundamental misconception that sustainability and the environment are one and the same issue. With possibly that the improvement towards using misapplied BRS so far may lead to a reduction of environmental chaos. Derived conclusions from a research [5] are given towards promotion of Sustainable buildings - for designing, construction and maintenance in order to protect public interest, sustainable and healthy environment for all in Region.

The example taken for expansible city type is Pristina, capital city of Kosovo, Kosovo's wealthiest municipality, grown from a small trading town, with 18,000 habitants in 1910; to a recorded 20,000 inhabitants in $1948 ; 108,000$ by 1981 and approximately more than 550,000 inhabitants recently. This growth, developments and the proceedings of economic and political changes within two late decades have impacted upon the achievement of the city's Strategic Plans and developers. Rapid growth effected beyond the harmonic balance of community, environment and economy. Actually, habitants, area and cost aren't harmonically apprehended. For a long time, the sustainability environment is seen by many as a restraint on development and only recently has it been recognized as a justified restraint on inappropriate development. In despite an extensive number of studies regarding the methods for integration on BRS in process of construction industry 
legislation for AEC, a lack of consensus remains among researchers and practitioners regarding the applications of sustainable indicators in context of Kosovo. One of the essentials of sustainable AEC industry is to remain up to date and follow current trends. In this sense is it important to see the needs of an increased population, followed by the increased demand for better and friendly environment and lifestyle. Thus, the great demand for the natural resources, such as sunlight, atmosphere, water, land (includes all minerals) along with all vegetation has the oblique report with the AEC industry demands. Apparently, the world is facing several environmental, social and economic problems. The problems result essentially by the combination of three main factors such as world population growth; resource consumption and pollution of air, soil and water.

Moreover, there is a lack of capacity in terms of qualified and experienced environmental managers, necessary when rising expectation and speed of population, or when answering surfaced questions: can we maintain and improve live quality whiles radically improving the effectiveness in how we use all our resources, reducing pollution and waste, uncontrollable build environment, and manage sustainability environment? Which appropriate forms, contest, methods and authorities to use when building human and health environment?

\section{The relevance of construction sector to development BRS}

The construction sector is responsible for consuming about $40 \%$ of raw materials and $55 \%$ of extracted wood; the sector represents $40 \%$ of final energy consumption in Europe (Directive 31/2001/EU) and about 35\% emissions of greenhouse gases; construction activities generate about $22 \%$ of all waste generated in Europe [6]. The researchers [7], defined that the building sector is one of the biggest energy users and therefore a cause for being a $\mathrm{CO}_{2}$ emitter. According to the Kosovo Statistical Office of the Ministry of Public Administration, the total number of households in Kosovo is 370,000 , of which $10 \%$ or approximately 36,400 are apartments. This percentage of the housing stock consists of privatized apartments from the formerly public rental housing and new apartments' buildings block, and the other $90 \%$ is individual housing. Based on the information of PHE of Pristina the privatized housing stock is up to 50 years old and not refurbished, due to the lack of funds and longtime absence of complete legal framework. Also, after the war the new housing construction has increased, increasing home ownership and therefore electricity consumption. The Annual Average Consumption (AAC) of final energy for the 
period 2001- 2005 for constriction sector is $4 \%$ and for private household $30.7 \%$ of total energy consumption. The economic and social global impact of the sector is also enormous. Construction is directly and indirectly related to almost $10 \%$ of GDP at the European level, it directly employs 12 million EU citizens and indirectly 26 million workers are dependent of this sector. The building sector produces also $17 \%$ of emissions of greenhouse gases. However, as mentioned above, the building sector accounts for about $40 \%$ of energy consumption. Thus, $40 \%$ of emissions in the energy sector are also related to the building, resulting in a total emission corresponding to this sector of approximately $28 \%[8]$.

The World Business Council for Sustainable Development (WBCSD) Vision 2050 report emphasize the way to sustainability and calls for a new agenda for business laying out a pathway to a world in which nine billion people can live well and within the planet's resources, by mid-century. The report is a consensus piece, compiled by 29 leading global companies, 14 industries and the result of an 18 month long combined effort between experts and dialogues with more than 200 companies and external stakeholders. This report addresses three questions: what does a sustainable world look like? How can we realize it? What are the roles business can play in ensuring more rapid progress toward that world? It is stetted also that we have what is needed to live well, within the limits of the planet: the scientific knowledge, proven and emerging technologies, financial assets and instant communications. Nevertheless, today our societies are on a dangerously unsustainable track. The story is one of growth in populations and consumption (in most countries) compounded by inertia stemming from inadequate governance and policy responses necessary to manage growth. The result could be degradation of the environment and societies [9].

\section{The importance of sustainability and BRS discussion and comparison}

The concept and definitions of the term "sustainable" is basically the maxim of ethic of reciprocity, a simple veracity: do onto future generations as you would have them do onto you, although the literature is replete with complex and sometimes conflicting definitions of the term. The most popular definition of sustainable development was published by the 1987 U.N. World Commission on Environment and Development (WCED). [10] It defined sustainable developments as those that "meet present needs without compromising the ability of future generations to meet their needs". Rosenbaum (1993) offers a similar and 
succinct definition that focuses on present responsibility versus long-term effect: "Sustainable means using methods, systems and materials that won't deplete resources or harm natural cycles" [11]. New, complex and constantly evolving sustainable design and construction practices have created a wide spectrum of published opinion about the definition, appropriate application and future direction of the concept and practice. This dearth of information has created a continuum of apprehension that ranges from a fear of reduced environmental laws weakening protection of the natural environment to the position that sustainable methods should be the only accepted construction practices [12]. Most states and many major cities have incorporated sustainability, 'green' concept into their internal building requirements for new construction. These green guidelines are used as benchmarks for green building incentive programs to build a green infrastructure too, necessary to mainstream green building practices, moreover practicing sustainable construction. There are currently many tools for assessing the sustainably of constructions, but there is issue to be taken into account such as s political, cultural, social and economic aspect of the site where it will be applied. Hence, given the subjectivity inherent in assessing sustainability, none of these methods is widely accepted.

The researchers [13] introduced the oldest tool for the analysis of the environmental assessment method for buildings is BREEAM, developed by researchers in UK and the private sector in 1988. It is estimated that over $30 \%$ of buildings in UK are assessed by this method. In order to allow assessments outside the United Kingdom there is nowadays the BREEAM International. LEED is an USA rating system, established in 1996 and managed by the NGO U.S. Green Building Council. The expansion of this system to the outside of the United States is notorious as this system is being used in many countries around the world. HQE is a French association founded in 1996 that brings together professionals in the construction sector with the aim to improving the environmental quality of construction. The label replaces the HPE HQE - Haute Performance Énergétique exists since early 1990. The SBTool is a rating system for sustainable construction developed through the participation of more than 20 countries since 1996. This tool was developed and is updated by the International Initiative for a Sustainable Build Environment (iiSBE). SBTool was aimed to allow the assessment and internationally comparison of the environmental performance of buildings. CASBEE is a Japanese system of environmental assessment of buildings and was developed by the Japan Sustainable Building Consortium in 2002. DGNB System is a German environmental assessment tool that was developed by the German Sustainable Building Council in 
cooperation with the Federal Ministry of Transport, Building and Urban Affairs and released in 2009 to be used to support the sustainable design and to assess the sustainability of buildings. The USGBC is considered the leader in promoting green/sustainable construction practices in the United States. The USGBC membership includes building developers, environmental leaders, retailers, financial industry leaders, architectural and engineering firms, product manufacturers and professional construction industry organizations. These members include the Construction Specification Institute, the American Institute of Architects, Turner Construction, Bovis Lend Lease, Johnson Controls, Ford Motorland, Herman Miller, the Natural Resources Defense Council, the Rocky Mountain Institute, Starbucks, Bank of America and numerous federal, state and local government agencies. In 1999, the USGBC introduced the LEED Green Building Rating System. Through its use as a design guideline and third-party certification tool, it aims to improve occupant wellbeing, environmental performance, and economic returns of buildings using established and innovative practices, standards and technologies. As of June 2004, its 4700 members had completed more than 1,400 LEED certified and registered projects across all 50 states [14].

Table 1. Mainstream Building Rating Systems.

\begin{tabular}{|c|c|c|c|c|c|}
\hline & LEEDS & GS & BREEAM & CASBEE & BCA_GM \\
\hline $\begin{array}{l}\text { Name of } \\
\text { System }\end{array}$ & $\begin{array}{l}\text { Leadership in } \\
\text { Energy \& } \\
\text { Environment } \\
\text { al Design }\end{array}$ & Green star & $\begin{array}{c}\text { Building } \\
\text { Research } \\
\text { Environment } \\
\text { Assessment } \\
\text { Method }\end{array}$ & $\begin{array}{l}\text { Comprehensive } \\
\text { Assessment } \\
\text { System for } \\
\text { Building } \\
\text { Environment } \\
\text { Efficiency }\end{array}$ & $\begin{array}{c}\text { BCA - Green } \\
\text { Mark }\end{array}$ \\
\hline Origin & USA & Australia & UK & Japan & Singapore \\
\hline $\begin{array}{l}\text { Managing } \\
\text { Organization }\end{array}$ & $\begin{array}{c}\text { United States } \\
\text { Green } \\
\text { Building } \\
\text { Council }\end{array}$ & $\begin{array}{c}\text { Green } \\
\text { Building } \\
\text { Council } \\
\text { Australia }\end{array}$ & $\begin{array}{c}\text { Green } \\
\text { Building } \\
\text { Council } \\
\text { Australia }\end{array}$ & $\begin{array}{l}\text { Japan Green } \\
\text { Build Council }\end{array}$ & $\begin{array}{c}\text { Building \& } \\
\text { Construction } \\
\text { Authority }\end{array}$ \\
\hline Launch Date & 2000 & 2002 & 1990 & 2001 & 2005 \\
\hline Ratings & $\begin{array}{l}\text { Certified, } \\
\text { Silver, Gold, } \\
\text { Platinum }\end{array}$ & $\begin{array}{l}1 \text { Star, } \\
2 \text { Star, } \\
3 \text { Star, } \\
4 \text { Star, } \\
5 \text { Star, } \\
6 \text { Star }\end{array}$ & $\begin{array}{c}\text { Pass, Good, } \\
\text { Very Good, } \\
\text { Excellent }\end{array}$ & $\mathrm{C}, \mathrm{B}-\mathrm{B}+\mathrm{B}, \mathrm{A}, \mathrm{S}$ & $\begin{array}{l}\text { Platinum, } \\
\text { Gold Plus }\end{array}$ \\
\hline $\begin{array}{l}\text { Area of } \\
\text { Coverage }\end{array}$ & USA & Australia & $\begin{array}{c}\text { United } \\
\text { Kingdom \& } \\
\text { some } \\
\text { European } \\
\text { Countries }\end{array}$ & Japan & Singapore \\
\hline
\end{tabular}




\section{OBJECTIVES}

A research aims that thought literature review and comparative method see comprehensive implementation of BRS worldwide disseminated approach that forms the basis for the sustainable environmental management of building sector generally in Kosovo, with intention to encourage responsible authorities to provide comprehensive guidelines and manage environmental consequences due to misapplied regulations of the sustainability ranting system of new and/or existing construction in context of Kosovo.

Regardless the sustainability assessment of buildings, comparable alternatives of buildings assessment management methods and in default of appropriate BRS as the benchmark for measuring the sustainability of new and/or existing buildings, focusing an attempt for appliances of it and solutions for management methods that can be successfully implemented in local level and/or regional level, in this case Pristina City. Since, buildings are major physical asset within every city, thus facility management deals with the management of built assets widely which will be well delivered the best service to the users, developers, property institutions and due to limited building condition. Thus, building rating system does the indicators of good performance, as it starts deteriorate once completed and been used, as well their affect to the sustainable environment. However, building rating system is just one part of a comprehensive policy package to achieve sustainability policy objectives. A BRS does not in and of itself improve building performance and its sustainability. Rather, the rating is essential for defining new and existing building performance and enabling other policies geared at i.e. reducing building energy consumption.

The general objective is to introduce the guidance scope of BRG, including: identifying the benchmarking best practices for new construction and major renovation while evaluating the construction's environmental performance, standards for certifying the design and construction of commercial or institutional buildings and high-rise residential buildings of all sizes, both public and private. The intent is to promote healthful, durable, affordable, and environmentally sound practices in building design and construction, basically in subject-matters such as Sustainable Sites (SS), Water Efficiency (WE), Energy and Atmosphere (EA), Materials and Resources (MR), Indoor Environmental Quality (IEQ), Innovation in Design (ID), Regional Priority (RP). Specific objective is increasing the awareness of importance of implementing of BRS in overall construction sectors; one of the largest ones of the Kosovo economy with tremendous 
impact on the environment and society. This study could help contractors' perceptions of green building practices by measuring the current levels of awareness and participation in BRS. The goal of implementing the BRS includes the identification and best practice of designing, construction and maintenance of construction; communicating common goals, experiences and methods. Ideal assessment method using the BRS identifies the most important attributes of a sustainable habitat, is measurable and accesses processes and motivations to comprehensible and multiple stockholders. The successful crossinstitutional assessment using the BRS presented in this paper deepens from the stages of development. A best result of implementing the BRS deepens as well from social structure and indicators within its content which are matters to decrease whitewashes, pursuing incremental and systemic change simultaneously, to increase habitat conscience by sustainable development education, and engaging it in cross-functional and crossinstitutional efforts. The final goal is to adapt best practices of BRS in local context.

\section{MATERIALS and METHODS}

The research was done by descripting and comparing mainstream rating systems. They have been research and compered to get information on whether or not to use BRS ranting indicators for Architectural, Engineering and Construction (AEC) industry in context of Kosovo. The analysis and evaluation of the 6 mainstream building rating systems among a lot of them related with LCC and BEES, are overviewed compered to be proposed in context of sustainable development of AEC industry in Kosovo; the type of guidelines, programs or scheme which will effectively encourage governmental or nongovernmental institutions to adopt the BRS usage.

Attainability to achieve sustainability of construction sector is only possible thought a real methodological work. The background information, state-of-art information identified at Pristina City, such as public administration's responsibility to enforce legislation, low level of social consciousness for sustainable and healthy environment, insufficiency of continues analysis for Sustainable Building Management and protection of public interest, were considered as a significant and an important part of causes that affected urban chaos recently. Thus, in order to have feasible sustainability the BRS should be carried out during the phases of design, to gather and report information for decisionmaking during the different faces of designing, construction and use of building, explicitly during entire building lice cycle. 
At the initial stage of design, clients have to be fully aware of regulatory requirements for sustainable development and follow it to producers, in order to accompany a planning application. In this case, BRS tool in design stage, shown in Figure 1, helps to develop an environmental policy statement that clearly shows out the objectives and advise the project teams on design options for meeting sustainability targets, e.g. low energy heating, natural ventilation systems, etc.; during construction stage BRS ensures the site registered under the 'considerate constructors' scheme and monitor delivery of sustainability goals - i.e. encourage the supply of materials from sustainable sources, the adoption of a sustainable waste strategy.

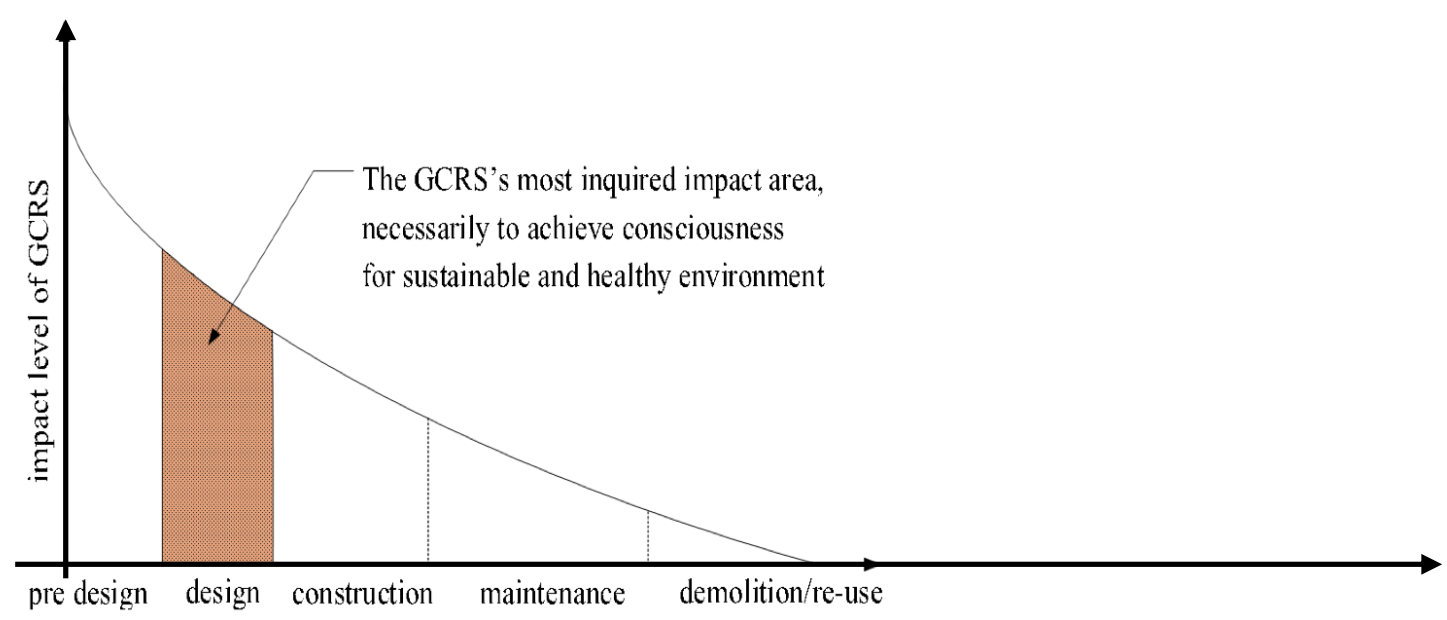

Figure 1. The imperative of using BRS during building life cycle (source: by authors).

Such tools are increasingly emerging as important solutions to decrease the impacts of the construction sector. The common indicators of above mentioned tools is that sustainability assessment of buildings in based in several goals that are much wider than the energy efficiency aims. While, there are certain definitions for sustainable building, generally speaking resources like energy, water, land, material, etc. should be considered in a much more efficient and effective way compares to conventional construction. The construction sector should produce buildings that are also designed and used in order to crate healthier living conditions and more productive working environments, through the use-reuse as much as possible natural resources, e.g. natural light and improved indoor environmental quality. Generally speaking, the Building Rating System (BRS) is like a report card for buildings, demonstrating to the community that a facility is built and/or operates in a way 
that supports the health and well-being of occupants and saves energy, resources and money following basic framework, shown in figure 2 .

(2) Principles - reduce resource consumption

- reuse resources

- recycle resources for reuse

- protect nature

- eliminate toxics

- apply life-cycle costing

- focus in quality

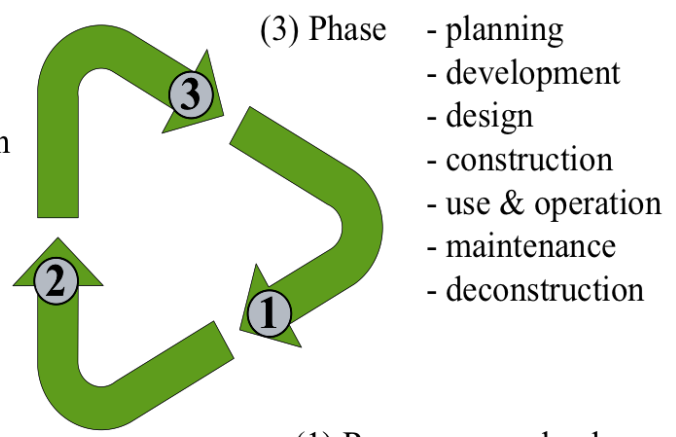

(1) Resources - land

- materials

- water

- energy

- ecosystems

Figure 2. The framework towards Sustainable Development when using BRS (source: by authors).

Regardless of what rating, standard, or guideline system is used, one should always ask who, organization or instructional authorities, will make an assessment. Is it being done by a first-party, second-party, or third-party? A first-party assessment is one that comes directly from an organization that is associated with the entity making or may benefit from the claim. A second-party assessment is not performed by an interested party. It might be done by a trade association, for example, and thus provides a level of independence from those who would directly benefit from a positive assessment. A thirdparty assessment is one that is done by an independent party that has no financial interest in the outcome of the assessment. There can be no direct payments, shares, loans, grants, or ties to members of the product or service being assessed. There are four principles that should be used when evaluating an assessment system:

- Science based - the results and decisions must be reproducible by others using the same standard;

- Transparent- the standards and process for awarding the certification should be transparent and open for examination;

- Objective - the certification body should be free of conflict;

- Progressive - the standard should advance industry practices, not simply reward business. 
Beside recapitulations of different BRS tools, the most appropriated and suggested rating system to further development into Kosovo's context could be LEED, or Leadership in Energy and Environmental Design, when redefining the way we think about the places where we live, work and learn. As an internationally recognized mark of excellence, LEED provides building owners and operators with a framework for identifying and implementing practical and measurable green building design, construction, operations and maintenance solutions.

\section{CONCLUSION}

Based on the analysis and comparison of the observable evidences for building rating systems developed recently in the world and appliance of standards for Sustainable Development generally in context of Kosovo, in regard to increase better understanding for all decision - makers and participants, the research presents suitable recommendations for principles, methods and checklists for sustainability of new constructions during entire life cycle. Explicitly, the role of appliance of BRS is emphasized by key findings in research, as follows:

- Implementation of BRS promotes overall benefits for environment, builders and end-user during entire AEC industry, explicitly during the design and construction stage;

- Applicability of BRS promotes and ensure users that the construction industry will start building in more sustainable way, with real improvements in key areas, such as: energy, carbon dioxide emissions, water use, better management of surface water run-off, usage of less pollution materials;

- The implementation of BRS methods and suggested tools improves environment today and sustainable environment of the region in the future and that will increase public attention and its conscience, e.g. through education and media concern over environmental issues, notably climate change, giving rise to a continues education among consumers for more sustainable products and services;

- The BRS increase the builder's performance towards sustainability performance of their Buildings, quality and efficient completion in that regards, lower running cost, improved comfort and satisfaction of tenants too;

- Provides valuable information to costumers / end-users, sufficient knowledge for sustainability performance of different buildings, assisting them in their choice for a new dwelling which should meet the sustainability criteria for a more pleasant and healthy place to live; 
- BRS should not be viewed as the ultimate goal by policy makers. Rather, these systems are one of several policy levers that policy makers can use to drive ultimate sustainable goals, i.e. energy efficiency or climate change goals. They have the greatest impact when they are integrated into strategic and coordinated energy efficiency or other policy framework including other key elements such as code enforcement, financial incentives, and a robust outreach and communications effort;

- The importance of ancillary systems supporting rating schemes, though are not limited to, such as: quality assessments, assessor training, public outreach, and maintaining an up-to-date and accurate data repository of building ratings and compliance, educational programs;

- Policy makers need to carefully evaluate how to best leverage the growing popularity of sustainability ratings without having energy performance become just one in long list of compliance items. Other researchers and analysis could also help to identify several other topics that would be useful for future research as well as additional topics that would merit international collaboration;

- As an alternative to creation of GCRS in Republic of Kosovo can be used the U.S. LEED rating system since it is notorious and continues to be used in many countries around the world.

Prerequisite towards successful implementation of GCRS is to create and maintain the credibility between decision- makers, participants and implementing body of GCRS.

\section{NOMENCLATURE}

$\begin{array}{ll}\boldsymbol{A E C} & \text { Architecture, Engineering and Construction } \\ \boldsymbol{A A C} & \text { Annual Average Consumption } \\ \boldsymbol{B R S} & \text { Building Rating System } \\ \boldsymbol{C O} & \text { Carbon monoxide } \\ \boldsymbol{E A} & \text { Energy and Atmosphere } \\ \boldsymbol{i i S B E} & \text { International Initiative for a Sustainable Build Environment } \\ \boldsymbol{I D} & \text { Innovation in Design } \\ \boldsymbol{I E Q} & \text { Indoor Environmental Quality } \\ \boldsymbol{S S} & \text { Sustainable Sites } \\ \boldsymbol{M R} & \text { Materials and Resources } \\ \boldsymbol{R P} & \text { Regional Priority } \\ \boldsymbol{W B C S D} & \text { World Business Council for Sustainable Development } \\ \boldsymbol{W E} & \text { Water Efficiency } \\ \boldsymbol{W C E D} & \text { World Commission on Environment and Development }\end{array}$




\section{REFERENCES}

[1] http://www.worldometers.info / (Accessed: February 16, 2018)

[2] https://www.iea.org/statistics / (Accessed:February 16, 2018)

[3] https://www.eea.europa.eu / (Accessed:February 16, 2018)

[4] Berardi, U., "Sustainability assessment in the construction sector: rating systems and rated buildings", (2011), Sustainable Development, Published online in Wiley online library, DOI 10.1002/sd.532

[5] Nushi, V., Bejtullahu, F., "Role of Codes for Sustainability Assessment of Construction", Proceedings of the International Conferences Sustainably of Construction towards a Better Build Environment, Final Conference of the COST Action C25, Innsbruck 2011, Austria, Published by Department of Civil \& Structural Engineering, University of Malta, Gutenberg Press, Malta, ISBN: 978-99957-816-06, Volume 1, pp. 175-183

[6] http://ec.europa.eu/eurostat/statistics-explained (Accessed: February 16, 2018)

[7] Brian H. Bowen PhD, James A. Myers PhD, et.al. "Kosovo Household Energy Consumption Facts and Figures" (2013) AUK-RIT Center for Energy \& Natural Resources, https://www.rit.edu/research/cenr/sites/rit.edu.research.cenr/pdf (Accessed: February 16, 2018)

[8] Kibert, C. J., (1999), "Reshaping the built environment: Ecology, ethics, and Economics", Washington, DC: Island Press

[9] https://sustainabledevelopment.un.org/milestones/wced

[10] https://rdmc.nottingham.ac.uk/bitstream/handle/internal/ (Accessed: February 16, 2018)

[11] Fujita, M., Krugman P. R., Venables, A. J., "The Spatial Economy: Cities, Regions, and International Trade", (1999), The MIT Press, DOI 10.2307/1061487

[12] Bragança, L., R. Mateus, and H. Koukkari. "Building Sustainability Assessment", Sustainability Journal (2010), 2(7): p. 2010-2023.

[13] Barbosa, J., et al, (2011) COST Action 025, (2011), Integrated approach towards Sustainable Construction, Malta: Gutenberg Press, Ltd

[14] http://www.usgbc.org (Accessed: February 16, 2018) 


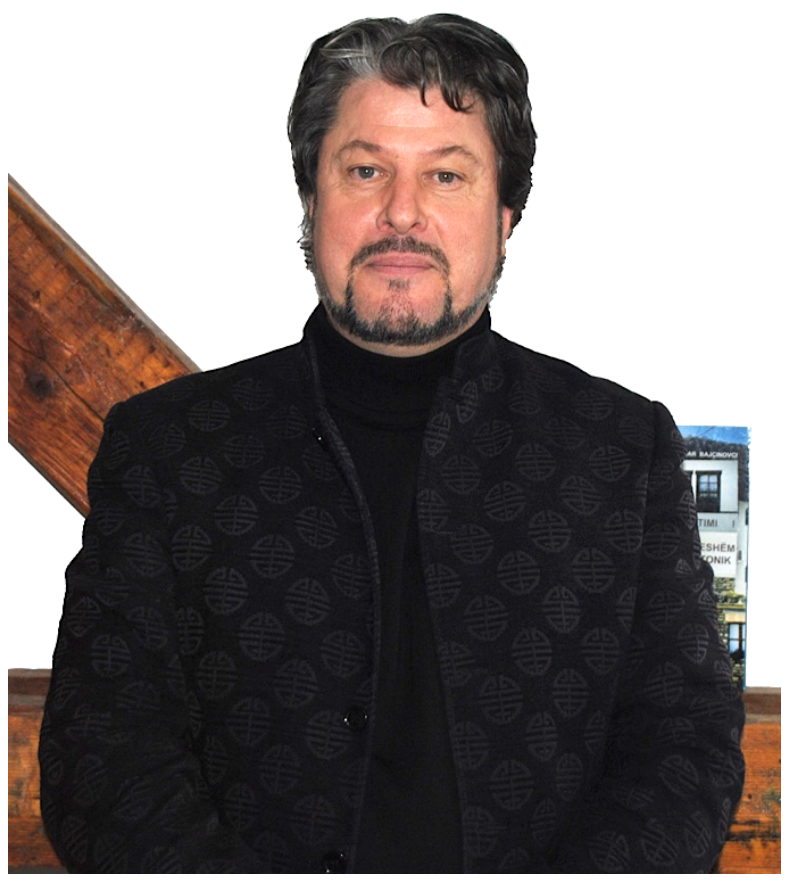

\section{Bujar Bajçinovci}

Architect, planner and professor, was born in Prishtina on 31/01/1965. Currently he teaches in the Department of Architecture - Faculty of Civil Engineering and Architecture, University of Prishtina, in Kosovo.

He received a Doctor of Technical Sciences grade in the field of Architecture and Urbanism from the Faculty of Architecture, University of Sarajevo, BiH (2012), and a Diploma in Architect Engineer from the University of Prishtina (1991). Since 1992 he has been a teaching assistant in Architectural Design courses at University of Prishtina. From 2017 he holds a position of Assistant Professor of the Architectural Design, as course Teacher in: Architectural Design 4, Architectural Design 5, Architectural Design 7, and Architectural Design Studio. Published more than 42 publications, also certified for Hybrid Teaching for the 21 st-Century Classroom, organized by Arizona State University - Melikian Center and University of Prishtina (2017). He was Senate member of the University of Prishtina in three mandates from 2004-2012. In 2008 he was member of the Strategic Development Committee at the University of Prishtina. His research interests focus on the field of Sustainable Architectural Design, Energy Efficiency, Renewable Energy in Building sector, and Environmental Pollution. Membership: International Academy of Sciences, Humanities and Arts. IASHA. Member of the Editorial Board: Pollution Research. Scopus Indexed Journal. Member of the Editorial Board: Ecology, Environment and Conservation. Scopus, and ISI Thomson Reuters, (U.S.A), Indexed Journal. 